agency and historical processes.

\title{
NOTES
}

${ }^{1}$ Quoting Methodist minister Peter Jones, Donald Smith points out that a "common mistake is, that the Messissauga [sic] Indians are distinct from the Ojibways, whereas they are a part of that nation, and speak the same language" (Jones qtd. xvi). British Canadians applied the label "Mississauga" to Anishinabeg (or Ojibwe-speakers) living on the north shore of Lake Ontario in the eighteenth and nineteenth century. The misnomer - much like "Indian" itself - remains in circulation.

2 Walter James Hoffman, The Mide'wiwin or "Grand Medicine Society" of the Ojibwa: Seventh Annual Report of the Bureau of Ethnology to the Secretary of the Smithsonian Institution, 1885-1886 (Washington, DC: Government Printing Office, 1891), 157 $-58,164-65,237,255$.

Brittany Luby

Laurentian University

\section{Bruce Erickson, Canoe Nation: Nature, Race, and the Making of a Canadian Icon (Vancouver: University of British Columbia Press, 2014). 252 pp. \$32.95 Paperback.}

Bruce Erickson's Canoe Nation: Nature, Race, and the Making of a Canadian Icon is a thorough exploration of the most mythologized vehicle in Canadian history. The canoe, so often touted as an embodiment of the nation itself, is stripped of its bark and thoroughly inspected. Erickson tracks the canoe from an Indigenous vehicle of necessity and ingenuity, through to sustained contact and its use in European economic and colonial subjugation. Once rendered obsolete by the steady march of capitalism, the canoe was reimagined as a recreational vehicle, and its role in the creation of Canada was fetishised to the extent that its inherent value became inextricably linked to its mythology.

It is this use of the canoe as a performance of nationhood that I find most compelling about Erickson's work. Nationhood, regardless of the reasons for its genesis, requires a certain amount of imagination to be sustained. (See: Benedict Anderson, Imagined Communities.) In any examination of a national identity - and we may want to put that prickly phrase in quotes - this is a given. In Canada, a country of absurdly large proportions and obversely minimal population, this is all we have. Since the idea of Canada has needed a carrier, that vehicle has been the canoe.

Erickson explores the nation via canoe in four chapters. The first examines pedagogical canoes and the often smoothed over versions of national histo- 
ry. He then outlines the rise of recreational canoeing and wilderness travel (spoiler alert, there is more about rods and guns than just fishing and hunting), before tackling the whiteness of the wilderness (or the whitening of it in order to exercise authority over it). He paddles home by discussing canoeing as political activism, before concluding with a discussion of the possibility for a politics of the canoe.

Erickson's strongest arguments come out of the idea of the "forced intimacy" between settlers and Indigenous peoples (52-53). Following an analysis of Foucault, and positing that power is not imposed but rather flows through people, Erickson demonstrates how the canoe facilitated bureaucratic tyranny in early Canada, as well as the establishment of a surveillance culture that coincided with biopolitical regulation (59-63). These are themes with which indigenous people in contemporary Canada remain tragically familiar.

According to Erickson, the canoe allows for the support of "regimes of whiteness" that sustain a dominant culture narrative, and relegate Indigenous people and cultures to tokenism. The white canoeist views Indigenous culture as archaic, romantic, and antithetical to contemporary Canada. The performance of canoeing thus reinforces the authority over country, something that was necessary once the canoe became the market's second choice for resource exploitation. One might go as far as to argue that recreational canoeing and the idea of Canada as a nation are intertwined.

While the work may have benefited from further engaging Indigenous perspectives in moving toward a politics of the canoe-the dual canoe analogy of the Two-Row Wampum remains a powerful political tool today-Erickson does an extraordinary job in pulling apart the ways in which the canoe is appropriated as a symbol of national culture and identity. The ubiquitous lovemaking in a canoe makes an appearance, but is accompanied by a refreshing and thought-provoking queering of the canoe (196). By queering the canoe and moving away from a look at the politics of the future, Erickson provides a powerful revelation: "Thinking through a politics of the canoe without a future means rethinking nature so that it is not bent toward the utility of power" (197).

In the face of the seemingly immortal Great Man practice of history, Erickson's deconstruction of how the canoe occupies, or rather facilitates the occupation of, Canada's founding mythos is essential reading. 